\title{
Comparison of Different Wood Species as Raw Materials for Bioenergy
}

\author{
Bojana Klašnja ${ }^{1 凶}$, Saša Orlović1, Zoran Galić1
}

${ }^{1}$ University of Novi Sad, Institute of Lowland Forestry and Environment, Antona Čehova 13, 21000 Novi Sad, Serbia

Corresponding author: e-mail: bklasnja@uns.ac.rs

Citation:

KLAŠNJA B, ORLOVIĆ S, GALIĆ Z 2013 Comparison of Different Wood Species as Raw Materials for Bioenergy. South-East Eur For 4 (2): 81-88

\section{Abstract}

Background and Purpose: Most projections of the global energy use predict that biomass will be an important component of primary energy sources in the coming decades. Short rotation plantations have the potential to become an important source of renewable energy in Europe because of the high biomass yields, a good combustion quality as solid fuel, ecological advantages and comparatively low biomass production costs.

Materials and Methods: In this study, the wood of black locust Robinia pseudoacacia, white willow Salix alba L., poplars Populus deltoides and Populus $x$ euramericana cl.I-214, aged eight years were examined. Immediately after the felling, sample discs were taken to assess moisture content, ash content, the width of growth rings, wood densities and calorific values, according to the standard methodology.

Results: The mean values of willow, poplar and black locust wood density were $341 \mathrm{~kg} / \mathrm{m}^{3}, 336 \mathrm{~kg} / \mathrm{m}^{3}$ and $602 \mathrm{~kg} / \mathrm{m}^{3}$, respectively. The average heating values of willow poplar and black locust wood were $18.599 \mathrm{MJ} / \mathrm{kg}, 18.564 \mathrm{MJ} / \mathrm{kg}$ and $21.196 \mathrm{MJ} / \mathrm{kg}$, respectively. The FVI index (average values) was higher for black locust (17.186) than for poplar and willow clones, which were similar: 11.312 and 11.422 respectively.

Conclusions: Black locust wood with a higher density, calorific value and ash content compared to poplar and willow wood proved to be a more suitable raw material as RES. However, it is very important, from the aspect of the application of wood of these tree species as RES, to also consider the influence of the biomass yield per unit area of the plantations established as "energy plantations".

Keywords: Poplar, willow, black locust, growth ring width, ash content, wood density, calorific value, FVI

\section{INTRODUCTION}

Using renewable energies, such as biomass, which are by definition carbon neutral, may drastically reduce greenhouse gas emissions. Forest products act as substitutes for politically, socially and environmentally insecure fossil fuels. In the climate change context, agricultural greenhouse gas sinks may be instrumental in removing carbon from 
the atmosphere by changing the vegetation cover and improving management, switching from the conventional agricultural crops to forests [1].

In terms of using wood biomass for bioenergy and biofuels, it is important to consider not only the total yield but also the composition of biomass in relation to different energy conversion technologies. Compared with annual and perennial grasses, wood biomass in general has a higher content of lignin, lower cellulose and hemicelluloses contents, a higher energy value, a lower ash content and lower concentrations of problem elements such as $\mathrm{K}, \mathrm{Na}, \mathrm{Cl}, \mathrm{Si}$, and $\mathrm{S}$ [2]. These characteristics favour wood biomass for combustion, pyrolysis and gasification but suggest it is a less favourable feedstock for biological conversion to biofuels.

In order to use wood biomass as renewable energy sources it is necessary to provide adequate support of the state, as well as an adequately formulated national strategy, particularly in regard to the issue of using biomass as a renewable energy source.

In order to encourage the use of biomass for energy production, the Government of Serbia adopted the Action Plan for Biomass in 2010, which defined the strategy for the use of biomass as renewable energy sources, taking into account the potential of national strategies, legislation and European directives.
The Action Plan was defined as a document which should determine the measures for promoting biomass in heat production and electricity generation and transport, followed by the subsequent actions related to the common problems of biomass supply, financing and research.

Serbia, as a country with large areas of arable land and forests, has a great potential for biomass production. Biomass accounts for $63 \%$ of the total potential of RES (Renewable Energy Sources). Forests cover approx. 30\% of the territory, and approx. 55\% of the territory is arable land. The total energy potential of biomass in the Republic of Serbia is estimated at 2.7 million toe (tonnes of oil equivalent), and it consists of residues in forestry and wood processing industry (approx. 1.5 million toe), and the rest in farming, livestock breeding, fruit growing, growing and primary processing of fruit (about 1.7 million toe).

It is evident that approx. $80 \%$ of wood biomass is used as firewood, while the remaining $20 \%$ represents wood residues from forests and the wood processing industry. Unfortunately, Serbia still lacks significantly large areas intended for "production" of the renewable biomass for energy needs.

The technical potential for short rotation energy crops production in Croatia [4] was estimated as forest area suitable for energy crops of 46850 ha, producing in total

TABLE 1. The possibility of energy production from biomass in Serbia - the biomass energy potential (according to FAO [3])

\begin{tabular}{lccc}
\hline \multicolumn{1}{c}{ Biomass source } & $\begin{array}{c}\text { Quantity } \\
\left(\mathrm{m}^{3}\right)\end{array}$ & $\begin{array}{c}\text { Share } \\
(\%)\end{array}$ & $\begin{array}{c}\text { Biomass potential } \\
\text { (toe) }\end{array}$ \\
\hline Wood biomass & 6840958 & 100.0 & 1527678 \\
Firewood & 5521758 & 80.7 & 1150000 \\
Forest residue & 572000 & 8.4 & 163760 \\
Wood process.industry residue & 627200 & 9.2 & 179563 \\
Wood from trees outside the forest & 120000 & 1.7 & 34355 \\
\hline Agricultural biomass & & & 1670240 \\
\hline Total biomass & & 3389223 \\
\hline
\end{tabular}

1 toe $=41.868 \mathrm{GJ}$ or $11.63 \mathrm{MWh}$ 
430000 tDM/y, or 7.9PJ, and agricultural areas with moderately suitable soils, and limited soil suitability of 235650 ha, producing of $2827800 \mathrm{tDM} / \mathrm{y}$, or 52.1PJ.

Therefore, the aim of this paper was to compare wood calorific values (heating values) of several clones of poplar, willow and black locust, which also represent the most promising species for plantations with a large number of plants per unit area in Serbia. The establishment of "energy plantations" with relatively short rotation cycles may, in relatively short time, produce very significant quantities of wood as a renewable resource for energy production. The results pertaining to determination of calorific value of wood, and also FVI index, which takes into account values of wood density, wood ash and moisture content used for obtaining heat energy, are quoted in this paper. In that way, a more realistic picture on the energy produced from biomass defined by the volume $\left(\mathrm{m}^{3}\right)$, as it is common in our forest practice, was obtained.

\section{MATERIALS AND METHODS}

In this study, the wood of 4 clones of black locust Robinia pseudoacacia, 11 clones of white willow Salix alba L., 7 clones of Populus deltoides and Populus $x$ euramericana cl.I-214, aged eight years were examined. After the selection of the characteristic sample trees (three trees in each clone) the measured parameters of growth elements were determined and the trees were felled. Sample trees were chosen as average plants based on the average diameter and height on the experimental plot. Immediately after the felling, samples discs (discs cut at breast height $-130 \mathrm{~cm}$ ) were taken to assess moisture content, ash content, width of growth rings and wood density. After the natural seasoning of samples for one month at room temperature, wood was ground into wood flour suitable for pellet pressing.

The wood density was determined on the basis of the oven-dry weight per green volume of an individual disk segment. Green volumes were obtained by soaking disk segments in water for 10 days until a constant volume was achieved. Excess moisture was removed from the surface of the sample, and each sample's water displacement (volume) was measured. The sample was then oven-dried to the constant weight at $1040 \mathrm{C}$ and weighed to determine the dry weight, i.e. to determine moisture content of wood samples, according to TAPPI standards T $12 \mathrm{wd}-82$. Ash content was determined by burning $5 \mathrm{~g}$ of a oven-dried and grounded sample in a platinum crucible in a muffle furnace at $5500 \mathrm{C} \pm 250 \mathrm{C}$, (TAPPI standards, T211 m-58). All analyses were done in duplicate and the results were expressed on a dry weight basis.

Calorific value was determined for ground air-dried samples. according to ASTM E87082 standard. The samples were combusted in the C200 IKA Werke calorimeter. However, calorific values were corrected for the moisture regained during storage. There were three replications for each sample.

Also FVI (fuel value index) was determined by the formula [5]:

$$
\mathrm{FVI}=\frac{\text { Calorific value }(\mathrm{kJ} / \mathrm{g}) \times \text { Density }\left(\mathrm{g} / \mathrm{cm}^{3}\right)}{\text { Ash content }(\mathrm{g} / \mathrm{g}) \times \text { Moisture content }(\mathrm{g} / \mathrm{g})}
$$

\section{RESULTS AND DISCUSSION}

The results of the analysis of variances regarding the width of the growth rings for all studied species are given in Table 2. As expected, the highest average values were recorded for all poplar clones, because the total average value was $13.51 \pm 1.54 \mathrm{~mm}$. The value of the average width of growth rings for all willow clones was somewhat lower: $9.50 \pm 1.98 \mathrm{~mm}$, while all black locust clones had the slowest growth, since the average width of the ring growth was $6.14 \pm 0.75 \mathrm{~mm}$. Differences in the width of growth rings between the clones measured within one wood species varied considerably, especially for poplar, while the differences for black locust were less significant, i.e. 
TABLE 2. The width of the growth rings in the examined wood species

\begin{tabular}{lcccc}
\hline \multicolumn{1}{c}{ Species } & $\begin{array}{c}\text { Width of growth } \\
\text { rings }(\mathrm{mm})\end{array}$ & $\begin{array}{c}\text { Min value } \\
(\mathrm{mm})\end{array}$ & Max value $(\mathrm{mm})$ & $\begin{array}{c}\text { Significance between } \\
\text { clones }\end{array}$ \\
\hline Willow & $9.50 \pm 1.98$ & 5.44 & 13.15 & $\mathrm{~F}>\mathrm{F}_{99.9}\left(^{* * *}\right)$ \\
Black locust & $6.14 \pm 0.75$ & 4.25 & 7.43 & $\mathrm{~ns}$ \\
Poplar & $13.51 \pm 1.54$ & 10.78 & 17.12 & $\mathrm{~F}^{*} \mathrm{~F}_{99}(* *)$ \\
\hline
\end{tabular}

the growth was uniform for all black locust clones. The variations between replications were statistically not significant, and there were no significant differences. These values were expected, and they were in accordance with our previous results $[6,7,8]$.

The analysis of variances of wood density in the studied clones is given in Table 3. According to ANOVA test, variation between replications are statistically not significant The mean values of willow wood density ranged from $308 \mathrm{~kg} / \mathrm{m}^{3}$ to $390 \mathrm{~kg} / \mathrm{m}^{3}$, that of poplar from $284 \mathrm{~kg} / \mathrm{m}^{3}$ to $375 \mathrm{~kg} / \mathrm{m}^{3}$, while the mean value of black locust was $602 \pm 32 \mathrm{~kg} / \mathrm{m}^{3}$. Differences between the clones within individual tree species were significant for poplar at the level of $\mathrm{P}=0.001$.

The results obtained in this study for willow wood were in accordance with our previous studies $[6,9,10]$. According to the data mentioned by Tharakan [11], the values of the specific gravity of willow wood ranged from 0.33 to 0.48 . Leclerq [12], also the quoted data for specific gravity ranging from 0.337 to 0.454 . According to Monteoliva [13], the values of wood density of the 13-year-old willow wood ranged from $364 \mathrm{~kg} / \mathrm{m}^{3}$ to $455 \mathrm{~kg} / \mathrm{m}^{3}$. Earlier investigtains in Croatia [14] concerning production of willow biomass in short rotations indicate that biomass share above the ground increased with the age, and the most productive trispecies hybrid had the most favourable relation between the plant underground and above the ground parts.

The values of wood density of black locust were in accordance with our previous results $[7,8,15]$. According to the literature, the specific gravity of black locust was approx. $0.69[16,17,18]$. Geyer and Walawender [19] determined the values of the specific gravity for 7-year-old black locust wood to be 0.58 . It was also in accordance with the results of Hernea [20], who found that the average values of several black locust clones ranged from $532 \mathrm{~kg} / \mathrm{m}^{3}$ to $648 \mathrm{~kg} / \mathrm{m}^{3}$ (basic wood density).

The values of poplar wood density were in good correlation with the studies carried out on a continual basis by the Institute of Lowland Forestry and Environment at Novi Sad. As it is well-known, the values of the wood density for the clone I-214 were the lowest (approx. $300 \mathrm{~kg} / \mathrm{m}^{3}$ ), while the clones of $P$. deltoides had significantly higher values of wood density [21, 22]. The results of the research conducted in Croatia [23] confirm that even at such a young plantation age ( 5 to 7 years), the quality of particular habitat of some poplar clones has conditioned modifications in average clone

TABLE 3. The wood density results of the examined wood species samples

\begin{tabular}{lcccc}
\hline \multicolumn{1}{c}{ Species } & $\begin{array}{c}\text { Wood density } \\
\left(\mathrm{kg} / \mathrm{m}^{3}\right)\end{array}$ & $\begin{array}{c}\text { Min value } \\
\left(\mathrm{kg} / \mathrm{m}^{3}\right)\end{array}$ & $\begin{array}{c}\text { Max value } \\
\left(\mathrm{kg} / \mathrm{m}^{3}\right)\end{array}$ & $\begin{array}{c}\text { Significance between } \\
\text { clones }\end{array}$ \\
\hline Willow & $336 \pm 17.386$ & 308 & 390 & $\mathrm{~F}>\mathrm{F}_{99}(* *)$ \\
Black locust & $602 \pm 32.603$ & 543 & 659 & $\left.\mathrm{~F}>\mathrm{F}_{99}{ }^{(* *}\right)$ \\
Poplar & $341 \pm 23.864$ & 284 & 375 & $\mathrm{~F}>\mathrm{F}_{99.9}\left(^{* * *}\right)$ \\
\hline
\end{tabular}


TABLE 4. The ash content of the examined wood species

\begin{tabular}{lcccc}
\hline \multicolumn{1}{c}{ Species } & $\begin{array}{c}\text { Ash content } \\
(\%)\end{array}$ & $\begin{array}{c}\text { Min value } \\
(\%)\end{array}$ & $\begin{array}{c}\text { Max value } \\
(\%)\end{array}$ & $\begin{array}{c}\text { Significance between } \\
\text { clones }\end{array}$ \\
\hline Willow & $0.56 \pm 0.08$ & 0.45 & 0.72 & $\mathrm{~F}>\mathrm{F}_{99.9}\left(^{* * *}\right)$ \\
Black locust & $0.77 \pm 0.05$ & 0.69 & 0.89 & $\mathrm{~F}>\mathrm{F}_{99}\left(^{* *}\right)$ \\
Poplar & $0.59 \pm 0.04$ & 0.52 & 0.69 & $\mathrm{~F}>\mathrm{F}_{99}\left(^{* *}\right)$ \\
\hline
\end{tabular}

values of growing stock and survival. They also indicate the amount of production to be expected from the mixture of these clones or from the cultivation of particular clone.

Since the ash content of wood is very significant if wood is used as fuel, all the studied clones were analysed to determine their ash content. Although it is known that the content of the inorganic compounds of wood in the mentioned tree species is low (generally does not exceed 1\%), for the calculation of the FVI index accurate values were needed, which are given in Table 4.

Significant differences in values of observed wood characteristics between the studied clones were analysed and proven for all studied tree species, while the differences between replications within the same clone were statistically insignificant. The ash content of the black locust tree was higher compared to that of poplar and willow, which influenced the values of the FVI index of the studied tree species.

The energy yield is a relevant criterion for using biomass as fuel. In relation to the harvested biomass, the energy yield was mainly determined by the contents of energyrich compounds, such as lignin, resin or cellulose. The mean energy content related to the dry matter of biomass is, therefore, a stable feature within a particular type of biomass and more or less independent of external factors. The average heating values of the analysed poplar clones (Table 5), ranged in a very narrow interval from $18.254 \mathrm{MJ} / \mathrm{kg}$ (clone S6-36) to $18,812 \mathrm{MJ} / \mathrm{kg}$ (clone S1-7). This corresponded fully with the values of our previous research $[6,20]$, and the values reported by Ciria et al. [24] for the heating values of poplar wood (3-5-year-old stem and branches) $18.1 \mathrm{MJ} / \mathrm{kg}$ to $18.3 \mathrm{MJ} / \mathrm{kg}$. Benetka et al. [25] for the 1 to 3-year-old poplar clones (wood at breast height and the basal part, and branches) reported heating values from $18.60 \mathrm{MJ} / \mathrm{kg}$ to $19.27 \mathrm{MJ} / \mathrm{kg}$.

The calorific values of willow wood were very similar and ranged from $18.028 \mathrm{MJ} /$ $\mathrm{kg}$ (clone 347) to $18.993 \mathrm{MJ} / \mathrm{kg}$ for the NS$73 / 6$ clone (on average $18.599 \mathrm{MJ} / \mathrm{kg}$ ). These values were in accordance with the values from our previous studies [7, 9], and with the values obtained by Szczukowski et al. [26], and Tharakan et al.,[27], approx. $19 \mathrm{MJ} / \mathrm{kg}$. Higher heating values for black locust ranging from $20.396 \mathrm{MJ} / \mathrm{kg}$ to $21.956 \mathrm{MJ} / \mathrm{kg}$ significantly differed among the clones $(P=0.001)$, and were somewhat higher than the cited in references: $19.578 \mathrm{MJ} / \mathrm{kg}$ [14]; $18.858 \mathrm{MJ} / \mathrm{kg}$ [19] for 7-year-old trees, i.e. from $17.72 \mathrm{MJ} / \mathrm{kg}$ to $18.14 \mathrm{MJ} / \mathrm{kg}$ [28] .

TABLE 5. The calorific values of the examined wood species samples

\begin{tabular}{lcccc}
\hline \multicolumn{1}{c}{ Species } & $\begin{array}{c}\text { Calorific value } \\
(\mathrm{MJ} / \mathrm{kg})\end{array}$ & $\begin{array}{c}\text { Min value } \\
(\mathrm{MJ} / \mathrm{kg})\end{array}$ & $\begin{array}{c}\text { Max value } \\
(\mathrm{MJ} / \mathrm{kg})\end{array}$ & $\begin{array}{c}\text { Significance be- } \\
\text { tween clones }\end{array}$ \\
\hline Willow & $18.599 \pm 0.282$ & 18.028 & 18.993 & $\mathrm{~ns}$ \\
Black locust & $21.196 \pm 0.315$ & 20.396 & 21.956 & ${\mathrm{~F}>\mathrm{F}_{99}(* * *)}$ \\
Poplar & $18.564 \pm 0.151$ & 18.254 & 18.812 & ${\mathrm{~F}>\mathrm{F}_{99.9}(* * *)}$ \\
\hline
\end{tabular}




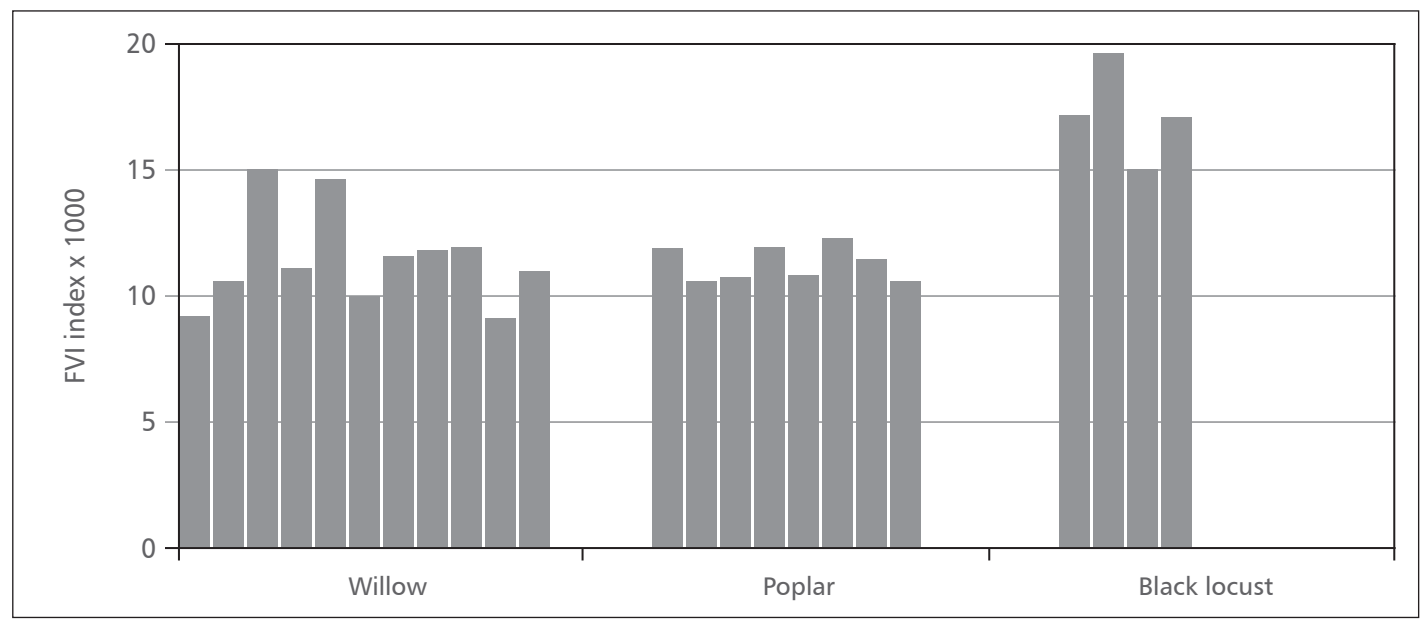

FIGURE 1. The FVI index values of the examined tree species

The FVI index (average values) was higher for black locust (17.186) than for poplar and willow clones, which were similar: 11.312 and 11.422 respectively. The statistical analysis of $\mathrm{FVI}$ index values for willow clones showed significant interclonal differences $(P=0.001)$, and the values (Figure 1) ranged from 9.110 ( $\mathrm{min}$ ) for the clone NS 79/2 to 14.648 (max) for the clone 107/65-7. The values of the $\mathrm{FVI}$ index for the tested poplar clones ranged from 10.646 (clone S6-36) to 12.322 (clone S1-7) with interclonal difference at $P=0.01$ probability.

FVI index values of black locust tree shown in Figure 1 were significantly higher compared to the values of poplar and willow and ranging from 14.931 (clone R113) to 19.630 (clone R56). This is quite logical since the FVI index takes into account the values of wood density and ash content. A high ash content is less desirable for fuel wood as it non-combustible and reduces the heat of combustion. The results of the calculated $\mathrm{FVI}$ indexes indicated that a higher value of wood density may contribute to the heating value of wood combustion. In fact, although the ash content of black locust was higher compared to that of poplar and willow, the higher calorific value and black locust wood density had a decisive influence.

\section{CONCLUSIONS}

Black locust wood with a higher density, a higher calorific value and a higher ash content compared to poplar and willow wood proved to be the more suitable raw material that may be used as a renewable energy source, regarding the production of heat energy (by combustion) per biomass weight $(\mathrm{kg})$.

However, it is very important, from the aspect of the application of wood of these tree species as renewable raw materials for energy, to also consider the influence of the biomass annual yield per unit area of the plantations established as "energy plantations".

In fact, although the three studied wood species belong to the group of fast growing deciduous species, it is necessary to determine the yield of biomass per hectare and to estimate the quantity of energy that may be produced by a comparative analysis. The stands may be established on the same soil types, under similar technological conditions - the type of planting material, stand density (the number of plants per hectare), the duration of the rotation cycle, the number of cycles, the way of stand regeneration after felling, supplementary nutrition and protection regimes, etc. Only after such a comprehensive analysis an assessment of the 
suitability of certain wood species as energy raw materials may be given.

Wood density and calorific value may be used as useful parameters for determining harvest rotation cycles, particularly for short rotation plantations. However, decisions would be specific for each wood species on a given site. Both the biomass production and soil quality are important considerations to determine the optimum cutting age for fast growing energy plantations. These results indicate the possibility of energy production from whole very young trees from short rotation plantations, chipped together with branches and bark, which would significantly increase the energy potential due to the relatively large share of the bark and its high calorific value Based on the testing and research conducted in Croatia [4], considerable potential for short rotation energy crops production recognized. Currently a very small ammount of the avaliable area is utilised, and issues and problems to be addressed in order to increase this production include a change in policy approach.

\section{Acknowledgement}

This paper was realized as a part of the project "Studying Climate Change and its Influence on the Environment: Impacts, Adaptation and Mitigation" (43007) financed by the Ministry of Education and Science of the Republic of Serbia within the framework of the integrated and interdisciplinary research for the period 2011-2014.

\section{REFERENCES}

1. BARAL A, GUHA G S 2004 Trees for Carbon Sequestration of Fossil Fuel Substitution: The Issue of Cost Vs, Carbon Benefit. Biomass Bioenerg 27 (1): 41-55. DOI: http://dx.doi.org/10.1016/j. biombioe.2003.11.004

2. KARP A, SHIELD I 2008 Bioenergy from plants and the sustainable yield challenge. New Phytol 179 (1): 15-32. DOI: http://dx.doi.org/10.1111/j.14698137.2008.02432.x

3. GLAVONJIC B 2009 Current situatuion in woody biomass in Serbia (in Serbian). In: Ulaganje u bioenergiju u Srbiji: šanse i izazovi. Novi Sad, Serbia, 7 September 2009

4. KAJBA D, DOMAC J, ŠENON V 2011 Estimation of Short Rotation Crops Potential in the Republic of Croatia: Illustration Case Within FP7 Project Biomass Energy Europe. Sumar list 135 (7-8): 361-370

5. GOEL V, BEHL H M 1996 Fuelwood quality of promising tree species for alkaline soil sites in relation to tree age. Biomass Bioenerg 10 (1): 57-61. DOI: http://dx.doi.org/10.1016/09619534(95)00053-4

6. KLAŠNJA B, KOPITOVIĆ Š 1997 Structuralphysical characteristics and chemical composition of wood of some white willow clones (Salix alba L.). Drevarsky vyskum 42 (1): 1-10
7. KLAŠNJA B, KOPITOVIĆ Š 1999 Quality of wood of some willow and robinia clones as fuelwood. Drevarsky vyskum 44 (2): 9-18

8. KLAŠNJA B, ORLOVIĆ S, GALIĆ Z, NOVČIĆ Z 2011 Physical and structural properties of wood of some black locust clones in different age (in Serbian with English summary). Topola (Poplar) 187-188: 15-24

9. KLAŠNJA B, KOPITOVIĆ Š, ORLOVIĆ S 2002 Wood and bark of some poplar and willow clones as fuelwood. Biomass Bioenerg 23 (6): 427-432. DOI: http://dx.doi.org/10.1016/S0961-9534(02)00069-7

10. KLAŠNJA B, ORLOVIĆ S, GALIĆ Z, KEBERT M 2010 Chemical composition and physical properties of wood of some clones of white willow (Salix alba) (in Serbian with English summary). Topola (Poplar)185-186: 41-50

11. THARAKAN $P J$, VOLK $T A$, ABRAHANSON $L P$, WHITE E H 2003 Energy feedstock characteristics of willow and hybrid poplar clones at harvest age. Biomass Bioenerg 25 (6): 571-580. DOI: http:/l dx.doi.org/10.1016/S0961-9534(03)00054-0

12. LECLERQ A 1997 Wood quality of white willow. Biotechnol Agron Soc 1 (1): 59-64 
13. MONTEOLIVA S, SENISTERRA G, MARLATS R 2005 Variation of wood density and fibre length in six willow clones (Salix spp.) AWA Journal 26 (2): 197-202

14. KAJBA D, KRSTINIĆ A, KOMLENOVIĆ N 1998 Arborescent willow biomass production in short rotation (in Croatian with English summary). Sumar list 122 (3-4): 139-145

15. KLAŠNJA B, KOPITOVIĆ Š 1995 Parallel examination of some characteristics of young Robinia wood. Drevarsky vyskum 40 (2): 1-9

16. STRINGER J W 1992 Wood properties of black locust (Robinia pseudoacacia L.): physical, mechanical, quantitative chemical variability. In: Hanover J W, Miller K, Plesko S (eds) Proceedings of International Conference on Black Locust: Biology, Culture and Cultivation, Michigan State University, Minnesota, USA, 17-21 June 1991, pp 178-191

17. REDEI K, OSVATH-BUJTASH Z, VEPERDI I 2008 Black Locust (Robinia pseudoacacia L.) Improvement in Hungary: a Review. Acta Silv Lign Hun 4: 127-132

18. REDEI K, CSIHA I, KESERU Z 2011 Black locust (Robinia pseudoacacia L.) Short-Rotation Crops under Marginal Site Conditions. Acta Silv Lign Hun 7: 125-132

19. GEYER W A, WALAWENDER W P 1994 Biomass properties and gasification behavior of young black locust. Wood Fiber Sci 26 (3): 354-359

20. HERNEA C, CORNEANU M, VISOLU D 2009 Reserches concearning the wood density of Robinia pseudoacacaia L. var. Ortenica. Journal of Horticulture, Forestry and Biotechnology 13: 334-336

21. KLAŠNJA B, ORLOVIĆ S, PEKEČ S, DREKIĆ M 2003 Influence of plant density on young eastern cottonwood wood density (in Serbian with English summary). Topola (Poplar) 171-172: 25-34
22. KLAŠNJA B, ORLOVIĆ S, GALIĆ Z, DREKIĆ M 2006 Poplar biomass of short rotation plantations as renewable energy raw material. In: Columbus $\mathrm{F}$ (ed) Biomass and Bioenergy New Research. Nova Science Publishers INC, New York, USA, pp 35-66

23. KAJBA D, ANDRIĆ I 2012 Estimation of genetic gain, productivity and phenotypic stability of poplar clones in the area of Eastern Croatia (in Croatian with English summary). Sumar list 136 (5-6): 235-243

24. CIRIA M P, MAZÓN M, CARRASCO J, FERNANDEZ J 1995 Biomass for energy, environment, agriculture and industry. In: Proceedings of the Eighth European Biomass Conference, Vienna, Austria, pp 489-494

25. BENETKA V, BARTAKOVA I, MOTTL J 2002 Productivity of Populus nigra L. ssp nigra under short rotation culture in marginal areas. Biomass Bioenerg 23 (5): 327-336. DOI: http://dx.doi. org/10.1016/S0961-9534(02)00065-X

26. SZCZUKOWSKI S, TWORKOWSKI J, KLASA A, STOLARSKI M 2002 Productivity and chemical composition of wood tissues of short rotation willow coppice cultivated on arable land. Rostilna vyroba 48 (9): 413-417

27. THARAKAN $P$ J, VOLK $T$ A, LINDSEY C A, ABRAHAMSON L P, WHITE E H 2005 Evaluating the impact of three incentive programs on the economics of cofiring willow biomass with coal in New York State. Energ Policy 33 (3):337-347. DOI: http://dx.doi.org/10.1016/j.enpol.2003.08.004

28. KRASZKIEWICZ A 2013 Evaluation of the possibilty of energy use black locust (Robinia pseudoacacaia L.) dendromass acquired in forest stands growing on clay soils. Journal of Central European Agriculture 14 (1): 388-399. DOI: http:// dx.doi.org/10.5513/JCEA01/14.1.1212 